\title{
ОСОБЕННОСТИ ПРОЯВЛЕНИЯ ХРОНИЧЕСКОГО КОРМОВОГО МИКОТОКСИКОЗА У ЛАБОРАТОРНЫХ КРЫС В УСЛОВИЯХ ЭКСПЕРИМЕНТА
}

\section{М.П. СЕМЕНЕНКО ${ }^{1}$, Е.В. ТЯПКИНА 1 , Е.В. КУЗЬМИНОВА' ${ }^{1}$, А.Г. КОЩАЕВ 2}

Микотоксикозы - специфические заболевания человека и животных, вызываемые
определенными видами микроспорических грибов, которые в процессе жизнедеятельности обра-
зуют микотоксины. Токсические эффекты этих веществ зависят от дозы токсина, длительности
его поступления в организм, вида, пола и возраста животного. Отсутствие данных о физиологи-
ческом механизме патологического воздействия при сочетанных микотоксикозах значительно
сокращает разработку новых лекарственных препаратов и методов лечения микотоксикозов жи-
вотных. В проведенном нами исследовании впервые были выявлены особенности клинико-
биохимического и патоморфологического проявления ассоциативных микотоксикозов при экспе-
риментальном воздействии наиболее часто встречающихся микотоксинов на лабораторных жи-
вотных. Целью нашей работы было изучение клинической картины хронического сочетанного
микотоксикоза у лабораторных крыс и патологоанатомических изменений органов и тканей при
поражении микотоксинами, а также особенностей симптоматики интоксикации, влияния микоток-
синов на воспроизводительную функцю крыс, полученное от них потомство, морфо-биохимические
показатели крови. Опыты проводили на бб белых нелинейных крысах обоих полов с массой тела 80-120 г (виварий Краснодарского научно-исследовательского ветеринарного института, 2018 год). Крысы были разделены на две группы (по 33 животных в каждой) методом парных аналогов. На протяжении 21 сут крысы из опытной группы получали корм, естественным образом контаминированный микотоксинами, из контрольной - доброкачественный корм. Количество спор гриба Fusarium sp. в зараженном корме составляло $5,7 \times 10^{4}$, Mucor sp. $-1,2 \times 10^{4}$, Penicillum sp. $2,0 \times 10^{4}$. Содержание микотоксинов в пробе превышало максимально допустимый уровень (зеараленон - 3,6 мг/кг, охратоксин А - 0,2 мг/кг, фумонизин В $_{1}-6,2$ мг/кг), что было подтверждено биопробой на лабораторных мышах. В течение экспериментального периода за всеми животными осуществлялся клинический контроль по следующим критериям: общее состояние, поедаемость корма, поведение, реакция на внешние раздражители, характер двигательной активности, состояние кожного и шерстного покровов, осязательная чувствительность, функции органов пищеварения и мочеотделения, корнеальный и кожный рефлексы, динамика приростов массы тела. Проводили гематологические исследования крови. В конце исследования в опытной и контрольной группах были убиты по три крысы для выявления патологоанатомических изменений. Скармливание животным токсичного корма привело к снижению массы тела на $21 \%$ относительно контроля, а также оказало неблагоприятное действие на процессы онтогенеза и развития, проявляющиеся высокой степенью мертворождения потомства, низкой массой и жизненными показателями родившихся крысят. В крови у животных опытной группы наблюдалось снижение количества эритроцитов на $17,0 \%(p \leq 0,05)$, гемоглобина - на $13,0 \%(p \leq 0,05)$, общего белка - на $23,7 \%$ (р $\leq 0,01)$, глюкозы - на $22,7 \%$, холестерина - на $28,9 \%$, триглицеридов - на $22,7 \%$ $(\mathbf{p} \leq \mathbf{0 , 0 5})$. Отмечали наличие реактивного лейкоцитоза как ответной реакции органов лейкопоэза на интоксикацию и возможный аллергический процесс, а также повышение ферментативной активности аланин- и аспартатаминотрансферазы в сыворотке крови соответственно на 40,5 и 61,3\% $(\mathbf{p} \leq \mathbf{0 , 0 1 )}$ по сравнению с контрольной группой. Установлено экссудативное геморрагическое воспаление слизистой оболочки желудка, тонкого и толстого отделов кишечника, отечность и полнокровие легких, увеличение печени, почек и сердца. Гистологическое исследование тканей печени выявило уменьшение количества гликогена в гепатоцитах, наличие участков с зернистой и жировой дистрофией, вакуолизацию гепатоцитов, пролиферацию желчных протоков, приводящих к тяжелым деструктивным и некротическим процессам. В почках отмечена зернистая и жировая дистрофия эпителия извитых канальцев, десквамация эпителиальных клеток, пролиферация, в сердце - изменения поперечной исчерченности волокон, нарушение кровообращения в сердечной мышще, утолщение эндокарда. В селезенке наблюдалось истощение лимфоидных элементов и уменьшение лимфатических фолликулов (мальпигиевых телец), в матке - разрастание и кариокинез клеток мускулатуры. Таким образом, были выявлены глубокие нарушения гомеостаза лабораторных животных, а также множественные патологические изменения органов и систем организма, вызванные сочетанным микотоксикозом.

Ключевые слова: микотоксины, биохимические показатели крови, лабораторные крысы, патологоанатомические исследования, органы.

Продуктивное и физиологическое здоровье сельскохозяйственных 
животных в значительной степени зависит от состава и качества потребляемых кормовых рационов, которое в том числе определяется содержанием плесневых грибов и микотоксинов (1-4).

Для своего развития плесневые грибы используют большинство составных элементов зерна, что приводит к значительным потерям его питательных и биологически активных веществ. Изменяется цвет, запах, вкус зерна. Но еще более опасно накопление в нем высокотоксичных метаболитов микроспорических грибов - микотоксинов, из которых наиболее распространены трихоценовые микотоксины (Т-2 токсин, дезоксиниваленол - ДОН, зеараленон), афлатоксин, охратоксин, стеригматоцистин (5, 6). Список микотоксинов продолжает расширяться, на сегодняшний день выявлено порядка 350 видов токсинообразующих грибов (14 родов) и более 520 микотоксинов, представляющих опасность для человека и животных (7-9).

Достоверно установлено, что потребление кормов, содержащих микотоксины, вызывает уменышение продуктивности (и, как следствие, снижение приростов живой массы молодняка), перерасход кормов на единицу продукции, ухудшение качества продукции (10-12). При этом микотоксины выявляются не только в кормах для сельскохозяйственных животных и птицы, но и могут попадать в пищевую продукцию, прошедшую технологическую обработку, что грозит развитием ряда заболеваний человека, в том числе онкологических. Это послужило причиной усиления внимания к вопросам получения биологически полноценной и безвредной животноводческой продукции со стороны многих транснациональных сообществ World Health Organization, Food and Agriculture Organization, United Nations Environment Programme, International Agency for Research on Cancer (13-15). При одновременном поступлении в организм двух или нескольких микотоксинов либо их сочетаний с токсичными загрязнителями (пестицидами, диоксинами, тяжелыми металлами) степень микотоксикологической опасности возрастает многократно, что может не только значительно усиливать токсичность продуктов жизнедеятельности микроспорических грибов, но и оказать существенное негативное влияние на здоровье животных $(16,17)$.

Направленность действия микотоксинов на организм и тяжесть патологического процесса зависят от множества факторов, к которым следует отнести дозы, длительность поступления токсинов в организм, вид животного, его пол и возраст. Однако во всех случаях происходит поражение жизненно важных органов и систем организма $(18,19)$. При этом до сих пор недостаточно исследовано патологическое воздействие сочетанных микотоксикозов на физиологические системы и органы, а также механизм такого воздействия, что уменышает возможности разработки препаратов и способов лечения животных. Увеличение масштабов экспорта и импорта зерна между странами и постепенное изменение климата в мире способствует значительному возрастанию повсеместной пораженности кормовых культур различными микотоксинами, что может привести к неконтролируемому загрязнению кормов токсическими метаболитами грибов (20-22).

В случае сочетанного действия микотоксинов, при котором их совместное влияние на организм резко усиливается, оценить тяжесть патологического развития микотоксикоза очень сложно. Оно зависит не только от ассоциации отдельных микотоксинов, но и от их концентраций, что выдвигает вопросы мониторинга клинической картины микотоксикозов у животных на одно из первых мест по актуальности исследовательских программ по микотоксикологии (23-25).

В проведенной нами работе впервые были выявлены особенности 
клинико-биохимического и патоморфологического проявления ассоциативных микотоксикозов при экспериментальном воздействии наиболее часто встречающихся микотоксинов на организм лабораторных животных.

Нашей целью было изучение клинической картины хронического сочетанного микотоксикоза и патологоанатомических изменений органов и тканей при поражении микотоксинами, а также особенностей симптоматики интоксикации у лабораторных крыс, влияния микотоксинов на воспроизводительную функцию животных, полученное от них потомство, морфо-биохимические показатели крови.

Методика. Экспериментальный хронический ассоциативный микотоксикоз моделировали на 66 белых нелинейных крысах обоих полов с массой тела 80-120 г, разделенных на две группы по 33 особи в каждой (15 самок и 18 самцов) (стационарные условия вивария Краснодарского научно-исследовательского ветеринарного института, 2018 год). Для эксперимента выбирали клинически здоровых животных, имеющих гладкий блестящий шерстный покров, бледно-розовую окраску видимых слизистых оболочек, хороший аппетит. Длительность карантина (акклиматизационного периода) составляла 14 сут. Кормление производили в фиксированное время полноценным стандартным пищевым рационом согласно установленным нормам. Доступ к воде не ограничивали.

На протяжении 21 сут опытная группа крыс получала корм, естественным образом контаминированный микотоксинами, контрольная группа - доброкачественный корм. В обеих группах поение осуществлялось вволю. С даты подсадки самцов в группы при обнаружении беременности определяли влияние токсичного корма на эмбриональное развитие и генеративную функцию животных.

В процессе микологического, токсико-биологического и иммуноферментного анализа проб, отобранных согласно регламенту отбора и транспортировки кормов для санитарно-гигиенических и химико-токсикологических исследований (ГОСТ 13586.3-83), определяли содержание спор грибов. В течение экспериментального периода за всеми животными осуществлялся клинический контроль по следующим критериям: общее состояние, поедаемость корма, поведение, реакция на внешние раздражители, характер двигательной активности, состояние кожного и шерстного покровов, осязательная чувствительность, функции органов пищеварения и мочеотделения, корнеальный и кожный рефлексы, динамика приростов живой массы.

Кровь для исследований брали у пяти крыс из каждой группы в конце экспериментального периода непосредственно из сердца под эфирными наркозом. Гематологические исследования крови проводили на автоматическом гематологическом анализаторе для диагностики in vitro Mythic18 («C2 DIAGNOSTICS S.A.», Швейцария/Франция), биохимические - на автоматическом биохимическом анализаторе Vitalab Flexor Junior («Vital Scientific N.V.», Нидерланды) с помощью наборов фирмы «ELITech Clinical Systems» (Франция).

В конце исследования в опытной и контрольной группах с использованием наркотизации эфиром (с соблюдением принципов биоэтики) были убиты по три крысы для выявления патологоанатомических изменений. Воздействие микотоксинов на макро- и микроструктуры внутренних органов белых крыс оценивали после вскрытия животных с полным извлечением внутренних органов. Материал фиксировали в $10 \%$ растворе нейтрального формалина; проводку осуществляли общепринятыми в патоморфологии методами (26). Образцы окрашивали гематоксилином и эози- 
ном. При микрофотосъемке использовали микроскоп MS-300 («Micros», Австрия) и цифровую 10-мегапиксельную камеру Digital IXUS 970 IS («Canon, Inc.», Япония); увеличение $\times 150$ (окуляр $\times 15$, объектив $\times 10) ; \times 300$ (окуляр $\times 15, \times$ объектив 20$)$ и $\times 600$ (окуляр $\times 15$, объектив $\times 40)$.

Результаты обрабатывали с использованием пакета программ Statistica 6.0 («StatSoft, Inc.», США). Данные представлены как среднее значение $(M)$ и стандартная ошибка среднего $( \pm \mathrm{SEM})$. Достоверность различий между сериями определяли с помощью $t$-критерия Стьюдента.

Результаты. Содержание спор грибов в корме, который давали животным опытной группы, превышало максимально допустимый уровень (МДУ) $\left(5,7 \times 10^{4}\right.$ в 1 г корма), на основании чего комбикорм был признан

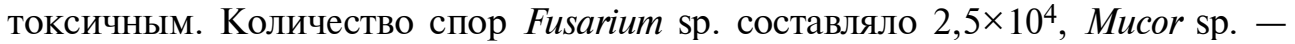
$1,2 \times 10^{4}$, Penicillum sp. $-2,0 \times 10^{4}$. Содержание микотоксинов в пробе также превышало МДУ (зеараленон - 3,6 мг/кг, охратоксин А - 0,2 мг/кг, фумонизин $\mathrm{B}_{1}-6,2$ мг/кг), что было подтверждено биопробой на лабораторных животных (мышах).

Первые признаки интоксикации микотоксинами у крыс из опытной группы были зарегистрированы уже на 5-7-е сут эксперимента. Это проявлялось излишней пугливостью с одновременным повышением возбудимости на фоне снижения спонтанной двигательной активности и развития адинамии. Шерстный покров был взъерошен, без блеска, с участками выпадения и загрязнения шерсти и алопеций. Отмечалось усиление жажды при снижении аппетита, что привело к заметному отставанию в росте к концу первого этапа опытного периода (табл. 1).

1. Живая масса белых нелинейных крыс при потреблении корма, контаминированного спорами и метаболитами микроскопических грибов $(M \pm \mathrm{SEM}, n=33)$

\begin{tabular}{|c|c|c|c|c|}
\hline \multirow{2}{*}{ Группа } & \multicolumn{2}{|c|}{ Масса тела, г } & \multirow{2}{*}{$\begin{array}{l}\text { Среднесуточный } \\
\text { прирост, г }\end{array}$} & \multirow{2}{*}{ К контролю, \% } \\
\hline & начало опыта & конец опыта & & \\
\hline Контрольная & $106,1 \pm 2,38$ & $131,7 \pm 3,12$ & $1,22 \pm 0,03$ & 100 \\
\hline Опытная & $103,8 \pm 2,33$ & $124,2 \pm 2,94$ & $0,97 \pm 0,04 *$ & 79,5 \\
\hline
\end{tabular}

Среднесуточный прирост массы тела у крыс опытной группы был ниже относительно контроля. Превышение этого показателя у контрольных аналогов составило $21 \%$ ( $\leq 0,05)$. В абсолютных единицах средние значения массы тела контрольных животных превысили показатели у крыс из опытной группы на 5,2 г.

Длительное потребление токсичного корма оказало неблагоприятное действие на гиногенез и процессы развития. К окончанию исследований в опытной группе выявили 6 беременных самок, в контрольной - 9. Хотя у крыс, получавших пораженный микотоксинами корм, беременность завершалась на 23-24-е сут естественными родами и по длительности не отличалась от беременности у контрольных самок, число новорожденных крысят у таких животных было незначительным (по 1-2 крысенка на самку). При этом из общего количества крысят, родившихся от самок опытной группы (10 гол.), два были мертворожденными, еще три оказались нежизнеспособными и погибли в течение первых 2 сут после родов. Однако уродств и аномалий в их развитии не отмечали. Средняя масса

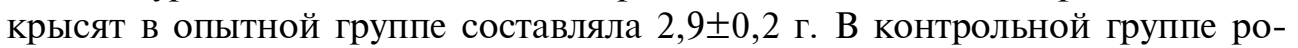

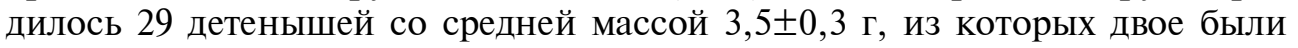
нежизнеспособными.

Интоксикацию оценивали по морфо-биохимическому профилю крови подопытных животных (табл. 2). У крыс из опытной группы регистри- 
ровали снижение гематологических параметров. К 21-м сут отмечалось уменьшение количества эритроцитов на $17,0 \%$ (p $\leq 0,05)$, гемоглобина - на $13,0 \%$ ( $\leq \leq 0,05)$ и повышение количества лейкоцитов на $21,4 \%$ ( $1 \leq 0,05)$ по сравнению с контролем. Следовательно, можно говорить об ингибировании эритро- и гемопоэза в результате длительной интоксикации организма. Наличие реактивного лейкоцитоза в крови у крыс, возникающее как реакция органов лейкопоэза на интоксикацию и возможный аллергический процесс, подтверждает это предположение.

2. Морфологические и биохимические показатели крови у белых нелинейных крыс при потреблении корма, контаминированного спорами и метаболитами микроскопических грибов $(M \pm \mathrm{SEM}, n=5)$

\begin{tabular}{|c|c|c|}
\hline \multirow{2}{*}{ Показатель } & \multicolumn{2}{|c|}{ Группа } \\
\hline & опытная & контрольная \\
\hline Эритроциты, $\times 10^{12} / л$ & $5,4 \pm 0,23^{* * *}$ & $6,3 \pm 0,31$ \\
\hline Лейкоциты, × $10^{9} /$ л & $9,8 \pm 0,57^{* *}$ & $8,07 \pm 0,29$ \\
\hline Гемоглобин, г/л & $113 \pm 3,74^{* * *}$ & $127,3 \pm 4,25$ \\
\hline Общий белок, г/л & $64,6 \pm 4,33^{* *}$ & $79,9 \pm 2,94$ \\
\hline Аспартатаминотрансфераза, ед/л & $150,7 \pm 6,41^{*}$ & $93,4 \pm 3,06$ \\
\hline Аланинаминотрансфераза, ед/л & $97,8 \pm 3,47^{*}$ & $69,6 \pm 6,13$ \\
\hline Щелочная фосфатаза, ед/л & $621,5 \pm 13,07$ & $547,3 \pm 21,84$ \\
\hline Глюкоза, ммоль/л & $6,6 \pm 0,42$ & $8,1 \pm 0,63$ \\
\hline Мочевина, ммоль/л & $8,4 \pm 0,31$ & $7,5 \pm 0,47$ \\
\hline Креатинин, мкмоль/л & $28,3 \pm 1,15$ & $25,3 \pm 1,1$ \\
\hline Холестерин, ммоль/л & $1,76 \pm 0,05^{*}$ & $2,27 \pm 0,14$ \\
\hline Триглицериды, ммоль/л & $0,44 \pm 0,03^{* * *}$ & $0,54 \pm 0,03$ \\
\hline
\end{tabular}
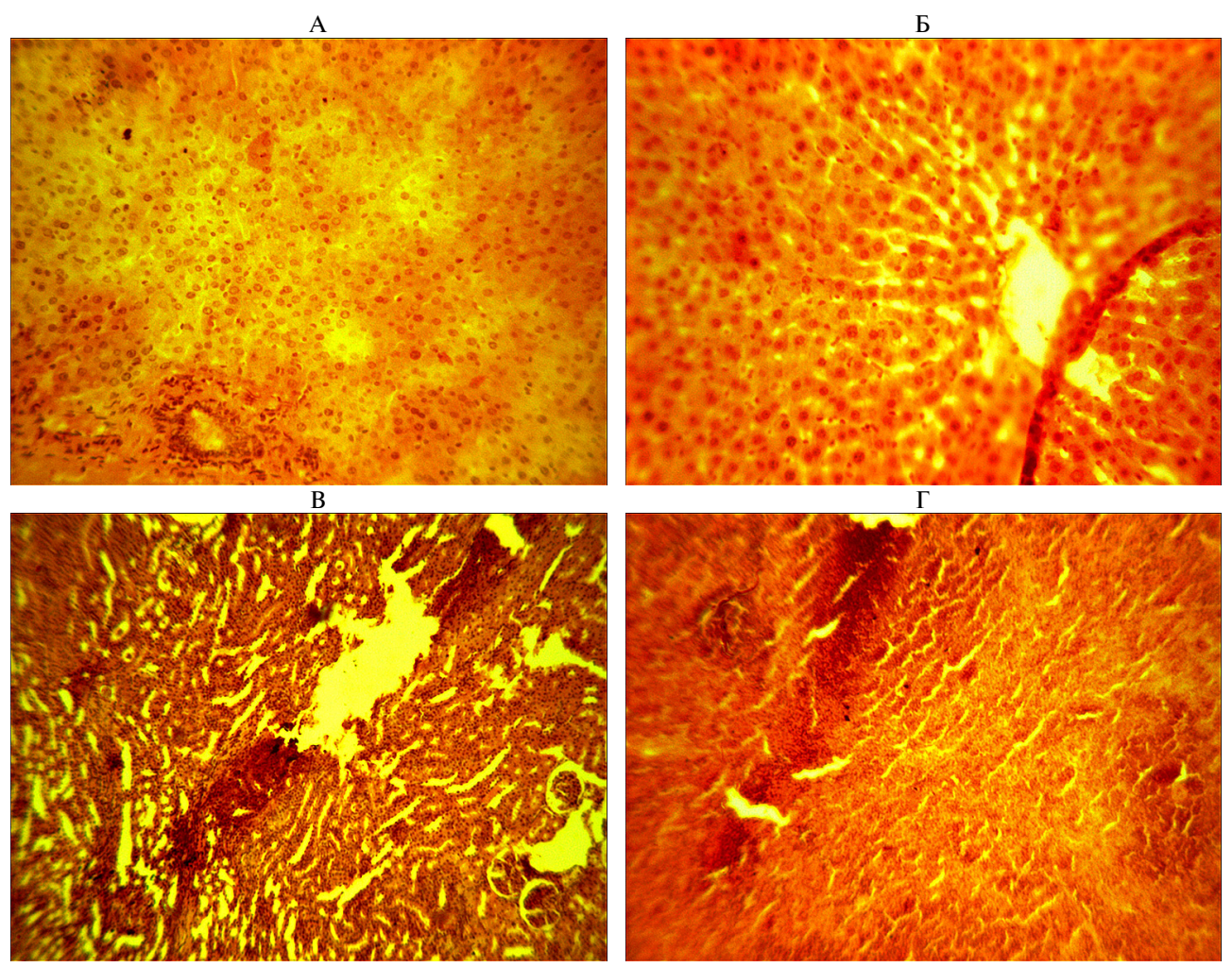

Зернистая дистрофия (А) и участки жирового перерождения печени (Б), пролиферация в почках (В) и селезенке (Г) у белых нелинейных крыс при потреблении корма, контаминированного спорами и метаболитами микроскопических грибов. Световая микроскопия (MS-300, «Micros», Австрия), окрашивание гематоксилином и эозином, увеличение $\times 150$ (А), ×300 (Б, Г) и ×600 (В).

В конце исследования при внешнем осмотре у крыс опытной груп- 
пы отмечали цианоз видимых слизистых оболочек, взъерошенность и тусклость шерстного покрова. Визуальное обследование внутренних органов крыс из опытной и контрольной групп не выявило нарушений в их расположении и строении. Однако у крыс опытной группы обнаруживали патологические изменения, проявляющиеся геморрагическим воспалением слизистой желудка, тонкого и толстого отделов кишечника, отечностью и полнокровием легких. Печень была темно-красного цвета, дряблая, увеличена, местами просматривались сероватые участки некроза, желчный пузырь переполнен. Сердце увеличено, с очагами микронекроза, сердечная мышца дряблая. Почки увеличены, розово-серого цвета, у самок вульва отечная, у самцов семенники увеличены в размерах.

При гистологическом исследовании (рис.) наиболее характерные изменения были обнаружены в тканях печени: в гепатоцитах уменьшалось количество гликогена, в цитоплазме имелись участки с зернистой и жировой дистрофией, просматривалась вакуолизация гепатоцитов, пролиферация в желчных протоках. В печеночных дольках нарушалось радиальное расположение балок из-за округления гепатоцитов. Все это указывало на наличие тяжелых деструктивных и некротических процессов в печени. В почках наблюдалась зернистая и жировая дистрофия эпителия извитых канальцев, десквамация эпителиальных клеток, пролиферация, в сердце - изменения поперечной исчерченности волокон, нарушение кровообращения в сердечной мышце, утолщение эндокарда. В селезенке происходило истощение лимфоидных элементов и уменьшение мальпигиевого слоя. В матке отмечали пролиферацию и митозы клеток мускулатуры.

В нашем исследовании мы установили высокую степень зараженности используемого в эксперименте корма спорами грибов, содержащих основные виды микотоксинов - зеараленон, охратоксин А, фумонизин $\mathrm{B}_{1}$, относящихся к сильнодействующим и высокотоксичным соединениям. Подобное сочетание приводит к усилению синергидного действия микотоксинов в организме, вследствие чего уже в 1-ю нед эксперимента периода у крыс отмечали клинические признаки токсикоза. Дальнейшее потребление токсичного корма усилила негативное влияние микотоксинов и привела к серьезным физиологическим сдвигам и патологическим процессам в органах размножения. Подобные проявления, на наш взгляд, связаны с наличием в корме зеараленона с превышением максимально допустимого уровни в 1,8 раза. Установлено, что этот микотоксин может вызывать бесплодие, аборты и кистообразование у животных. Выявленное в эксперименте негативное влияние ассоциации зеараленона, охратоксина А и фумонизина $\mathrm{B}_{1}$ на процессы оплодотворения у крыс и эмбриональное развитие их потомства согласуются с установленным свойствами Т-2 токсина и ДОН индуцировать апоптоз в эмбрионах животных, в том числе птицы (27).

Присутствие в кормовом рационе высоких доз охратоксина А (в 4 раза превышающих МДУ) приводит к угнетению гемо- и лейкопоэза, синтеза белка, ряда ферментов, поражению печени и почек, снижению живой массы и отставанию в росте, а сочетание нескольких микотоксинов усиливает их совместное патологическое влияние на организм (28). Сообщалось, что экспериментальный микотоксикоз у лабораторных мышей, вызванный скармливанием комбикормов контаминированных охратоксином и Т-2 токсином, проявляется следующими клиническими признаками: гиперемией видимых слизистых оболочек, расстройством нервной системы, ухудшением потребления корма, снижением живой массы, поражением же- 
лудочно-кишечного тракта, изменением биохимических показателей крови - уменьшением содержания амилазы и холестерина при одновременном увеличении количества мочевины и креатинина (29).

Ряд исследователей отмечают, что при потреблении кормов, загрязненных микотоксинами в естественных условиях, токсический эффект бывает выражен сильнее, чем при поступлении эквивалентного количества чистого микотоксина в эксперименте. В отношении Т-2 токсина и афлатоксина, трихотеценов и фузаровой кислоты, зеараленона и дезоксиниваленола имеются данные, подтверждающие эффекты их синергизма (30-34).

Обсуждая проблему хронических микотоксикозов, необходимо подчеркнуть, что усиление перекисного окисления липидов, наблюдаемое при микотоксикозах, приводит к повреждению мембран гепатоцитов, угнетению различных функций печени и в конечном итоге к развитию гепатопатий (35-38). Нами установлено, что при сочетанной естественной контаминации кормов зеараленоном, охратоксиом А и фумонизином $\mathrm{B}_{1}$ происходит развитие патологических процессов в печени по типу жировой дистрофии.

Таким образом, у белых нелинейных крыс экспериментальный сочетанный микотоксикоз характеризуется множественными токсическими проявлениями в клиническом состоянии животных: излишней пугливостью, въерошенностью и тусклостью шерстного покрова, аллопециями, усилением жажды и снижением аппетита, отставанием в росте и развитии, негативным влиянием на процессы оплодотворения самок и эмбрионального развития плодов (незначительное число новорожденных крысят, высокая мертворожденность и смертность, низкая масса тела при рождении). Морфо-биохимические показатели крови крыс при ассоциативном микотоксикозе имеют более низкие значения по эритроцитам и гемоглобину (на 17,0 и 13,0 \% при $\mathrm{p} \leq 0,05$ относительно аналогичных показателей у особей из контрольной группы) на фоне развития реактивного лейкоцитоза, отмечается гипопротеинемия, гипогликемия, нарушения липидного обмена при одновременном повышении активности трансаминаз печени (аланинаминотрансферазы - на 40,5 \%, аспартатаминотрансферазы - на 61,3\% при $\mathrm{p} \leq 0,01)$. При гистологическом исследовании печени подопытных животных выявлены участки зернистой и жировой дистрофии, вакуолизация и уменьшение количества гликогена в гепатоцитах, пролиферация в желчных протоках. В почках обнаружена зернистая и жировая дистрофия эпителия извитых канальцев, десквамация эпителиальных клеток, пролиферация, в сердце - изменения поперечной исчерченности волокон, нарушение кровообращения в сердечной мышще, утолщение эндокарда. В селезенке наблюдалось истощение лимфоидных элементов и уменьшение лимфатических фолликулов (мальпигиевых телец), в матке - разрастание и кариокинез клеток мускулатуры. Результаты исследований свидетельствуют о глубоких нарушениях гомеостаза лабораторных животных, а также о множественных патологических изменениях органов и систем организма, вызванных сочетанным микотоксикозом.

\section{ЛИТЕРАТУРА}

1. Иванов А.В., Фисинин В.И., Тремасов М.Я., Папуниди К.Ф. Микотоксикозы (биологические и ветеринарные аспекты). М., 2010.

2. Gruber-Dorninger C., Jenkins T., Schatzmayr G. Global mycotoxin occurrence in feed: a tenyear survey. Toxins (Basel), 2019, 11(7): 375 (doi: 10.3390/toxins11070375).

3. Marczuk J., Obremski K., Lutnicki K., Gajęcka M., Gajęcki M. Zearalenone and deoxynivalenol mycotoxicosis in dairy cattle herds. Polish Journal of Veterinary Sciences, 2012, 15(2): 365- 
372 (doi: 10.2478/v10181-012-0055-x).

4. The Mycotoxin Blue Book/D.E. Diaz (ed.). Nottingyam University Press, 2005.

5. Gajęcka M., Zielonka Ł., Jakimiuk E., Dąbrowski M., Obremski K., Gorlo G., Mróz M., Gajęcki M. Diagnostic significance of selected analytical indicators of zearalenone mycotoxicosis in animals. Medycyna Weterynaryina, 2012, 68(9): 566-570.

6. Тремасов М.Я., Иванов А.В., Папуниди К.Х., Семенов Э.И. Проблема микотоксикозов животных. Ветеринарный врач, 2010, 5: 16-19.

7. Михайлова И.И., Евглевская Е.П., Рыжкова Г.Ф., Михайлова О.Н. Микотоксикозы крупного рогатого скота. Зерноград, 2015.

8. Агольцов В.А., Попова О.М., Ларионов С.В. Микология и микотоксикология в ветеринарии и зоотехнии. М., 2015.

9. Goliński P., Waśkiewicz A., Gromadzka K. Mycotoxins and mycotoxicoses under climatic conditions of Poland. Polish Journal of Veterinary Sciences, 2009, 12(4): 581-588.

10. Streit E., Naehrer K., Rodrigues I., Schatzmayr G. Mycotoxin occurrence in feed and feed raw materials worldwide: long-term analysis with special focus on Europe and Asia. Journal of the Science of Food and Agriculture, 2013, 93(12): 2892-2899 (doi: 10.1002/jsfa.6225).

11. Changwa R., Abia W., Msagati T., Nyoni H., Ndleve K., Njobeh P. Multi-mycotoxin occurrence in dairy cattle feeds from the gauteng province of south Africa: a pilot study using UHPLC-QTOF-MS/MS. Toxins (Basel), 2018, 10(7): 294 (doi: 10.3390/toxins10070294).

12. Великанов В.В., Курдеко А.П., Мацинович А.А., Малков А.А., Лапина В.А. Патогенез, диагностика и профилактика кормового микотоксикоза (зеараленон) у молодняка свиней. Актуальные проблемы интенсивного развития животноводства (Горки), 2009, 12(1): 78-86.

13. Изосимова И.В., Аксенов И.В. Изучение содержания охратоксина А в продуктах питания, изготовленных на основе зерна кукурузы. Успехи медицинской микологии, 2015, 14(7): 296.

14. Girish C.K., Devegowda G. Efficacy of glucomannan-containing yeast product (Mycosorb) and hydrated sodium calcium aluminosilicate in preventing the individual and combined toxicity of aflatoxin and T-2 toxin in commercial broilers. Asian-Australasian Journal of Animal Sciences 2006, 19(6): 877-883 (doi: 10.5713/ajas.2006.877).

15. Berthiller F., Crews C., Dall'Asta C., Saeger S.D., Haesaert G., Karlovsky P., Oswald I.P., Seefelder W., Speijers G., Stroka J. Masked mycotoxins: a review. Moleculor Nutrition and Food Research, 2013, 57(1): 165-186 (doi: 10.1002/mnfr.201100764).

16. Иванов А.В., Тремасов М.Я., Папуниди К.Х., Чулков А.К. Микотоксикозы жсивотных (этиология, диагностика, лечение, профилактика). М., 2008.

17. Wada K., Endo H., Ogata Y., Ohtsuka H., Koiwa M., Nagahata H. Mycotoxins contamination of forage crops on a farm and attenuation of its harmful influence at three dairies. Japan Veterinary Medicine, 2007, 60: 425-429.

18. Матвеева Е.Л. Патоморфологические изменения у животных при смешанных микотоксикозах (опыты на белых крысах). Ученые записки Казанской государственной академии ветеринарной медицины, 2006, 187: 19-23.

19. Донник И.М., Безбородова Н.А., Бодрова О.С. Мониторинговые исследования кормов и сырья в Уральском регионе. Ветеринария Кубани, 2009, 1: 13-15.

20. Равилов А.3., Угрюмова В.С., Антипов В.А., Семененко М.П., Васильев В.Ф. Фармакологическая активность и эффективность энтеросорбента приминкор при микотоксикозах птиц и свиней. Технология животноводства, 2010, 9-10: 11-14.

21. Seeling K., Dänicke S. Relevance of the Fusarium toxins deoxynivalenol and zearalenone in ruminant nutrition. Journal of Animal and Feed Sciences, 2005, 14(1): 3-40 (doi: $10.22358 /$ jafs/66965/2005).

22. Sharma C., Aulerich R.J., Render J.A., Reimers T., Rottinghaus G.E., Kizilkaya K., Bursian S.J. Reproductive toxicity of ergot alkaloids in mink. Veterinary and Human Toxicology, 2002, 44(6): 324-327.

23. Obremski K., Gajęcki M., Otrocka-Domagata I., Rotkiewicz T., Zwierzchowski W., Zielonka Ł., Mikołajczyk A., Siemionek J. Clinical case of rabbit zearalenone mycotoxicosis. Medycyna weterynaryina, 2005, 61(4): 458-461.

24. Соколова Л.Н. Клинические и патоморфологические проявления субклинических микотоксикозов у птии. СПб, 2008: 136-140.

25. Ulianitskaja A.Y. Encephalopathy of aflatoxicosis and T-2 mycotoxicosis, origin, development and pathoanatomical description. Ветеринарная медицина, 2008, 89: 376-381.

26. Жаров А.В., Белоусов В.И., Барабанов И.И., Калмыков М.В., Гулюкин М.И., Суворов В.С., Яковлева Е.В. Методические указания по патогистологической технике. М., 2005.

27. Verma R.J. Aflatoxin causes DNA damage. International Journal of Human Genetics, 2004, 4(4): 231-236 (doi: 10.1080/09723757.2004.11885899).

28. Донник И.М., Безбородова Н.А. Мониторинговые исследования микотоксинов в корма и комбикормовом сырье в Уральском регионе. Аграрный вестник Урала, 2009, 8: 84-89.

29. Козина Е.А., Табаков Н.А. Использование адсорбентов в рационах мышей при скармли- 
вании зерна, содержащего микотоксины. Вестник КрасГАУ, 2011, 7: 123-126.

30. Varga J., Frisvad J.C., Samson R.A. Two new aflatoxin producing species and an overview of Aspergillus section Flavi. Studies of Mycology, 2011, 69(1): 57-80 (doi: 10.3114/sim.2011.69.05).

31. Streit E., Schatzmayr G., Tassis P., Tzika E., Marin D., Taranu I., Tabuc C., Nicolau A., Aprodu I., Puel O., Oswald I.P. Current situation of mycotoxin contamination and cooccurrence in animal feed-focus on Europe. Toxins (Basel), 2012, 4(10): 788-809 (doi: 10.3390/toxins4100788).

32. Richard J.L. Some major mycotoxins and their mycotoxicoses - an overview. International Journal of Food Microbiology, 2007, 119(1-2): 3-10 (doi: 10.1016/j.ijfoodmicro.2007.07.019).

33. Guerre P., Eeckhoutte C., Burgat V., Galtier P. The effects of T-2 toxin exposure on liver drug metabolizing enzymes in rabbit. Food Additives Contaminants, 2000, 17: 1019-1026 (doi: 10.1080/02652030050207819).

34. Speijers G.J.A., Speijers M.H.M. Combined toxic effects of mycotoxins. Toxicology Letters, 2004, 153(1): 91-98 (doi: 10.1016/j.toxlet.2004.04.046).

35. Ismaiel A.A., Papenbrock J. Mycotoxins: producing fungi and mechanisms of phytotoxicity. Agriculture, 2015, 5: 492-537 (doi: 10.3390/agriculture5030492).

36. Liu B.H., Wu T.S., Yu F.Y., Su C.C. Induction of oxidative stress response by the mycotoxin patulin in mammalian cells. Toxicological Sciences, 2007, 95(2): 340 (doi: 10.1093/toxsci/kfl156).

37. Mary V.S., Valdehita A., Navas J.M., Rubinstein H.R., Fernández-Cruz M.L. Effects of aflatoxin $\mathrm{B}_{1}$, fumonisin $\mathrm{B}_{1}$ and their mixture on the aryl hydrocarbon receptor and cytochrome P450 1A induction. Food and Chemical Toxicology, 2015, 75: 104-111 (doi: 10.1016/j.fct.2014.10.030).

38. Sun L.H., Lei M.Y., Zhang N.Y., Gao X., Li C., Krumm C.S., Qi D.S. Individual and combined cytotoxic effects of aflatoxin $\mathrm{B}_{1}$, zearalenone, deoxynivalenol and fumonisin $\mathrm{B}_{1}$ on $\mathrm{BRL}$ 3A rat liver cells. Toxicon, 2015, 95: 6-12 (doi: 10.1016/j.toxicon.2014.12.010).

\title{
1 ФГБНУ Краснодарский научный центр \\ Поступила в редакцию по зоотехнии и ветеринарии,
}

350055 Россия, г. Краснодар, пос. Знаменский, ул. Первомайская, 4, e-mail: sever291@mail.ru ( $\square$ corresponding author), jane-tyapkina@yandex.ru,niva1430@mail.ru;

2 ФГБОУ ВО Кубанский государственный аграрный университет им. И.Т. Трубилина, 350044 Россия, г. Краснодар, ул. Калинина, 13, e-mail: kagbio@mail.ru

Sel'skokhozyaistvennaya biologiya [Agricultural Biology], 2019, V. 54, № 4, pp. 777-786

\section{MANIFESTATIONS OF CHRONIC FEED MYCOTOXICOSIS IN LABORATORY RATS UNDER EXPERIMENTAL CONDITIONS}

\author{
M.P. Semenenko ${ }^{1}$, E.V. Tyapkina ${ }^{1}$, E.V. Kuzminova ${ }^{1}$, A.G. Koshchaev ${ }^{2}$
}

${ }^{1}$ Krasnodar Research Center for Animal Husbandry and Veterinary Medicine, 4, ul. Pervomaiskaya, pos. Znamenskii, Krasnodar, 350055 Russia, e-mail sever291@mail.ru ( $\square$ corresponding author);

${ }^{2}$ Trubilin Kuban State Agrarian University, 13, ul. Kalinina, Krasnodar, 350044 Russia, e-mail kagbio@mail.ru ORCID:

Semenenko M.P. orcid.org/0000-0001-8266-5900

Tyapkina E.V. orcid.org/0000-0002-0520-0357

The authors declare no conflict of interests

Received April 14, 2019

Kuzminova E.V. orcid.org/0000-0003-4744-0823

Koshchaev A.G. orcid.org/0000-0002-3904-2860

doi: 10.15389/agrobiology.2019.4.777eng

\section{Abstract}

Mycotoxicoses are specific human and animal diseases caused by the certain types of microspores fungi that during their life form toxic substances, the mycotoxins. Toxic effects of these diseases are diverse and depend on the dose of toxin, exposure, animal species, age and sex. Lack of data on physiological mechanism of the pathological influence under combined mycotoxicoses significantly reduces the development of new drugs and methods for treatment of animal mycotoxicoses. This paper is our first report on the features of the clinical, biochemical, and pathomorphological signs of associative mycotoxicoses under experimental exposure of laboratory animals to the most common mycotoxins. The aim of the research was studying clinical signs of chronic combined mycotoxicosis and pathoanatomical changes in organs and tissues under experimental mycotoxins in laboratory rats, as well as the characteristics of intoxication symptoms, the effect of mycotoxins on the reproductive function of rats and their progeny, and morphobiochemical blood parameters. Experiments were carried out on 66 white non-linear rats of both sexes with a body weight of 80-120 g (Krasnodar Research Veterinary Institute vivarium, 2018). After 14-day acclimatization (quarantine) the rats 
matching experimental conditions were divided into two groups, 33 animals each, according to paired analogue criterium. The experimental rats were fed for 21 days with the feed naturally contaminated by mycotoxins. The control rats ate toxin-free feed. The spore counts in the contaminated feed was $5.7 \times 10^{4}$ for Fusarium sp., $1.2 \times 10^{4}$ for Mucor sp., and $2.0 \times 10^{4}$ for Penicillum sp. Mycotoxin concentration in the samples exceeded the maximum permissible level $(3.6 \mathrm{mg} / \mathrm{kg}$ for zearalenone, $0.2 \mathrm{mg} / \mathrm{kg}$ for ochratoxin A, $6.2 \mathrm{mg} / \mathrm{kg}$ for fumonisin $\mathrm{B}_{1}$ ), which was confirmed by bioassay on laboratory animals (mice). During the experimental period, all animals were clinically monitored for general status, feed consumption, behavior, response to external stimuli, motor activity, skin and fur condition, tactile sensitivity, functions of the digestive and urinary organs, corneal and dermal reflexes, and dynamics of weight gain. Hematologic blood tests were also performed. At the end of the study, three rats were euthanized in the experimental group and three rats in control group to identify pathologic and anatomical changes. It was determined that toxic feed leads to a $21 \%$ decrease in body weight compared to the control, and also negatively impacts upon ontogenesis and reproduction causing a higher number of stillborn offspring and lower body weight and vitality of the newborn rats. In the blood of experimental animals the number of erythrocytes decreases by $17.0 \%$ $(\mathrm{p} \leq 0.05)$, hemoglobin by $13.0 \%(\mathrm{p} \leq 0.05)$, total protein by $23.7 \%(\mathrm{p} \leq 0.01)$, glucose by $22.7 \%$, cholesterol by $28.9 \%$, and triglycerides by $22.7 \%$ (p $\leq 0.05)$. Reactive leukocytosis developed as a response of leukopoiesis to intoxication and a possible allergic process. Activity of blood alanine and aspartate aminotransferases was 40.5 and $61.3 \%$ ( $\mathrm{p} \leq 0.01)$ higher, respectively, compared to the control rats. We also revealed exudative hemorrhagic inflammation of the mucous membrane of the stomach, thin and thick intestine, swelling and plethora of the lungs, enlarged liver, kidneys and heart. Histological examination of liver tissues showed a decrease in the amount of glycogen in hepatocytes, as well as the areas with granular and fatty dystrophy, vacuolization of hepatocytes, proliferation of the bile ducts, which may indicate severe destructive and necrotic processes. In the kidneys, a granular and fatty dystrophy of the convoluted tubule epithelium, desquamation of epithelial cells and proliferation occur, in the heart there are changes in the transverse striations of fibers, problems with blood circulation in the heart muscle and endocardial thickening. A depletion of lymphoid elements and a decrease in the lymphatic follicles (malpighian bodies) are characteristic of spleen. Proliferation and mitosis of muscle cells are found in the uterus. Thus, the combined mycotoxicosis deeply violates the homeostasis of laboratory animals and leads to multiple pathological changes in the organs and systems of the body.

Keywords: mycotoxins, biochemical indicators of blood, laboratory rats, pathological anatomical studies, organs.

\section{Научные собрания \\ IV МЕЖДУНАРОДНАЯ НАУЧНАЯ КОНФЕРЕНЦИЯ «СОВРЕМЕННОЕ СОСТОЯНИЕ, ПРОБЛЕМЫ И ПЕРСПЕКТИВЫ РАЗВИТИЯ АГРАРНОЙ НАУКИ, \\ И V МЕЖДУНАРОДНАЯ МОЛОДЕЖНАЯ ШКОЛА-КОНФЕРЕНЦИЯ «РОЛЬ МАКРО- И МИКРОЭЛЕМЕНТОВ В СОВРЕМЕННОМ ЗЕМЛЕДЕЛИИ»}

(9-13 сентября 2019 года, ФГБУН НИИСХ Крыма, г. Симферополь)
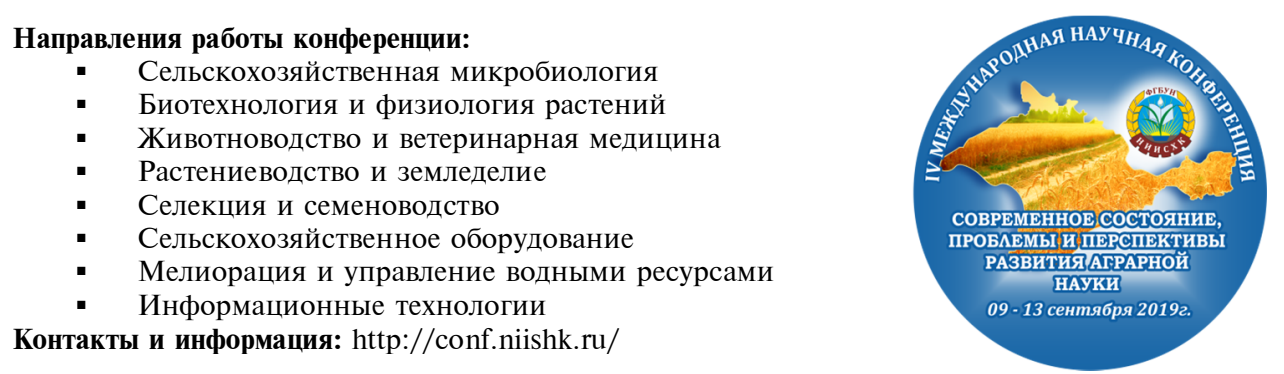

12th GLOBAL SUMMIT ON AQUACULTURE \& FISHERIES

(March 30-31, 2020, Hong Kong)

Theme: innovative and sustainable aquaculture

Aquaculture Summit 2020 will be innovative and skimpy international conference reflecting the direction of aquaculture and offers a wide range of diversions to members of all the backgrounds. This Aquaculture event harvesting will cover the new research systems and concentrate on aquaculture display of new nourishes, welfare, anti-infection agents, instruments presented by the aquaculture fisheries labs. It equally disguises the growth in the obligation for demanding ocean bottom. Aquaculture brings basic and propelled research of Developmental, Toxicological and Transgenic angles.

Information: https://aquaculture.global-summit.com/ 